\title{
Correlations between Endogen Amylin Hormone and Some Hormonal, Biochemical and Bone Parameters in Pullets
}

http://dx.doi.org/10.1590/1516-635x1604375-380

\section{author(s)}

Guzel S

Gunes $N^{\prime}$

Department of Biochemistry, Faculty of Veterinary Medicine, University of Uludağ, 16 059 - Görükle, Bursa, TURKEY

\section{ABSTRACT}

The objective of this study was to assess the correlations of amylin (a pancreatic polypeptide hormone) with some hormonal, biochemical and bone parameters in pullets. Forty 18-week-old pullets were used. Plasma amylin, CT (calcitonin), 1,25 (OH)2 vitamin D $(1,25$ dihydroxycholecalciferol ), serum osteocalcin, glucose, ALP (alkaline phosphatase), cholesterol, and triglycerides, as well as weight, length and total volume of tibiotarsi were measured. Plasma amylin concentration was negatively correlated with serum cholesterol $(p<0.05)$ and triglycerides $(p<0.05)$ concentrations. Plasma amylin concentration was significantly and positively correlated with plasma calcitonin concentrations $(p<0.001)$. Serum ALP and plasma amylin concentrations were positively correlated $(p<0.01)$. There were no correlations between amylin hormone and other parameters. Based on these results, it is possible to conclude that endogen amylin may effect cholesterol, triglycerides, calcitonin, and ALP levels in pullets without changing some other hormonal, biochemical and bone parameters related to calcium and lipid metabolism.

\section{INTRODUCTION}

Amylin is a hormone composed of a 37-amino acid peptide and was discovered in 1987 (Cornish et al., 1998a). Amylin, also known IAPP (islet amyloid polypeptide), is colocalized with insulin in the beta-cells of the pancreatic islets (Lebovitz, 2010). It is also found in much lesser quantities in the gastrointestinal tract and hypothalamus. Northernblot analysis indicates that IAPP mRNA is expressed in the chicken brain and intestine at a greater than 10 fold higher level than that found in the pancreas (Westermark et al., 2011). Receptors for amylin are highly concentrated especially in the central nervous system, area postrema and nucleus accumbens, but it is likely that they are present on the surface of osteoblasts and osteoclasts as well (Fu et al., 2013). There is a $20 \%$ sequence homology between amylin, CT (calcitonin) and adrenomedullin and 44\% homology with CGRP (calcitonin gene related peptide), because it is a member of the calcitonin family. Amylin is a potent osteoblast mitogen and, acting like $C T$, an inhibitor of bone resorption. Unreduced amylin contains an intact disulfide bond between the position 2 and 7 of the peptide (Granholm, 2011). Several experiments reported that this disulfide bond of the amylin molecule plays a key role in the amylin effects on bone and on the stimulation of osteoblast proliferation (Cornish et al., 1998a, b; Bronsky, 2004). Amylin and CGRP have been reported to have CT-like hypocalcemic activity in vivo. Both human amylin and CGRP inhibited 1,25 (OH) vitamin $\mathrm{D}(1,25$ dihydroxycholecalciferol)-induced bone resorption in a tissue culture system, and the biological potencies of the two peptides were approximately 60-fold lower than that recorded for human CT. 
Bone development of laying hens is critical in the egg industry. Pullets at the beginning of the laying period, undergo considerable metabolic stress, and required the supply of approximately $2.4 \mathrm{~g}$ calcium daily to the oviduct for shell formation. Dietary calcium supplies about 60 to $75 \%$ of the calcium required for eggshell formation, whereas the other 25 to $40 \%$ comes from bones (Newberry et al., 1999). Therefore, bone reserves are important in laying hens. It was reported that amylin increases bone cortical width in mice (Cornish et al., 1998a) and laying hens (Guzel et al., 2009).

Amylin is co-secreted with insulin from the $\beta$-cells of the pancreatic islets in response to stimulation of glucose, free fatty acids and food intake (Miegueu et al., 2013) Amylin is an important player in the control of energy balance. It inhibits food intake by supporting postprandial satiation, probably through stimulation of its receptor in the area postrema. Amylin increases energy expenditure after peripheral and central administration in animals (Lutz et al., 2006, 2010). Chronic infusion of amylin into the brain reduces body weight gain and adiposity, while chronic infusion of an antagonist of amylin receptors into the brain increases body adiposity (Lutz et al., 2010; Wielinga et al., 2010). In vitro, amylin was found to inhibit both basal and insulin-stimulated glycogenesis in rat skeleton muscle (Leighton et al., 1988) and to impair glucose disposal in liver cells (Hoppener et al., 2008). Infusion of amylin in dogs also induced peripheral insulin resistance (Xinwei et al., 2011). High levels of amylin are observed in obese children and obese adults with impaired glucose tolerance or type-2 diabetes (Reinehr et al., 2007). Cellular and animal studies implicate multiple roles of amylin in regulating insulin action and glucose and lipid metabolism. However, the relationships between amylin and serum glucose, cholesterol, and triglyceride levels in poultry has not been studied yet.

We carried out this study to evaluate if amylin has a relationship with $C T, 1,25(\mathrm{OH})_{2}$ vitamin $\mathrm{D}$, osteocalcin, ALP, glucose, triglyceride, and cholesterol level, as well with tibiotarsal weight, length and total volume in pullets.

\section{MATERIALS AND METHODS}

\section{Birds}

The experiment was performed with 40 layer pullets with 18 weeks of age. The mean \pm standard error (SEM) body weight of pullets was $1398 \pm 87 \mathrm{~g}$. Pullets were housed in the same room on deep litter and were fed ad libitum. The pullets had free access to water. The room temperature was maintained at 22 to $27^{\circ} \mathrm{C}$ and $12 \mathrm{~h} / \mathrm{d}$ of light was applied. The diets were formulated according to bird age (Table 1).

\begin{tabular}{lclc}
\hline $\begin{array}{l}\text { Table } \mathbf{1}-\text { Ingredients and } \\
\text { composition of pullet diets }\end{array}$ & & \\
\hline $\begin{array}{l}\text { Calculated nutrient } \\
\text { composition }\end{array}$ & $\%$ & \multicolumn{1}{c}{ Ingredient } & $(\%)$ \\
\hline & & Wheat bran & 3.90 \\
Crude protein (\%) & 18.03 & Corn Bran & 7 \\
ME (kcal/kg) & 2.70 & Corn & 45 \\
Calcium (\%) & 3.70 & Cotton seed meal, 44\% & 10 \\
Phosphorus (\%) & 0.68 & Soybean Meal, 44\% & 20.56 \\
Linoleic acid (\%) & 1.00 & Dicalcium phosphate & 1.83 \\
Methionine (\%) & 0.30 & DL-methionine & 0.08 \\
Lysine (\%) & 0.70 & Oyster shell & 5 \\
Av. Phosphrus (\%) & 0.40 & Limestone & 3.34 \\
& & L-Lysine hydrochloride & 0.10 \\
& & Vitamin-Mineral Mix & 0.30 \\
\hline
\end{tabular}

Vitamin and trace mineral premix supplied per kg of premix: vitamin A 280000 IU, vitamin D3 120000 IU, vitamin E 2000 mg, vitamin B1 3200, vitamin K3 1600 mg, vitamin B2 640 mg, vitamin B6 480 mg, vitamin B12 4.8 mg, pantothenic acid 1600 mg, niacin 2400, folic acid 160 mg, biotin 48 mg, choline chloride 160000 mg, Cu 800 mg, I 48 mg, Co 40 mg, Se 32 mg, Mn 9600mg, Fe 19200 mg, Zn 2400 mg, calcium D-pantothenate $320 \mathrm{mg}$, BHT $4000 \mathrm{mg}$, niacin $800 \mathrm{mg}$.

\section{Experimental Procedure}

All birds were weighed and sacrificed by cutting the neck veins. Blood samples were taken into vacutainers (Venoject, Terumo, Leuven, Belgium) containing EDTA as an anticoagulant and tubes with no anticoagulant (serum tube) on slaughtering day. The samples were immediately centrifuged at $3000 \times \mathrm{g}$ for $10 \mathrm{~min}$. Serum glucose, triglycerides, and cholesterol levels were measured on slaughtering day. The remaining serum and plasma were stored at $-80^{\circ} \mathrm{C}$ until the day of analysis.

\section{Chemical Analyses}

Serum glucose level was measured with a commercial kit (BD-D-GLUPAP-01, Fluitest, Biocon Diagnostik, Germany) using a spectrophotometer (Schimadzu UV 1601, Kyoto, Japan). Serum ALP, triglycerides, and cholesterol levels were also determined with a commercial kit (REF 80014, REF 80106 and REF 80019, respectively, Biolabo, Maizy, France) using spectrophotometer.

Plasma CT was measured with commercial ELISA kits (S-1227, Peninsula lab., Bachem group, San Carlos, (A). The intra-assay CV for CT was $6.4 \%$. Plasma $1,25(\mathrm{OH})_{2}$ vitamin $\mathrm{D}$ and serum osteocalcin were also measured with commercial ELISA kits (K2112, Immunodiagnostık AG, Bensheim; 99-0054, Zymed lab., California, USA, respectively). Before the 1,25 $(\mathrm{OH})_{2}$ vitamin D assay, plasma samples were extracted 
using the procedure of the $1,25(\mathrm{OH})_{2}$ vitamin $\mathrm{D}$ kit to separate $1,25(\mathrm{OH})_{2}$ vitamin $\mathrm{D}$ from other vitamin D metabolites, especially from the $25(\mathrm{OH})$ vitamin $D$ and $24,25(\mathrm{OH})$, vitamin $\mathrm{D}$. The intra-assay CV for osteocalcin and $1,25(\mathrm{OH})_{2}$ vitamin $\mathrm{D}$ were $0.6 \%$ and $3.9 \%$, respectively.

In order to determine tibiotarsal measurements (weight, length, volume), the right tibiotarsus of each bird was immediately dissected from surrounding tissues, the bone cap was removed and kept frozen in a plastic bag at $-20^{\circ} \mathrm{C}$ until measurement. Each frozen tibiotarsus was later thawed at room temperature for $1 \mathrm{~h}$ (14), and the tibiotarsal length was measured with a digital caliper (Mitutoyo Corporation, Kawasaki, Japan). Bone mass was weighed with digital scale (Precisa XB 4200C, Switzerland). Bone volume then was measured by immersing the bone into a liquidfilled graded cylinder.

\section{Statistical Analyses}

The SPSS ${ }^{\circledR}$ statistical software 13.00 was used for statistical analysis. Data were expressed as mean and standard error. The relationship between plasma amylin and plasma CT, 1,25 (OH) 2 vitamin D and serum osteocalcin, glucose, triglycerides, cholesterol, ALP and tibiotarsal weight, length and total volume were analyzed using Pearson's correlation coefficient and $p<0.05$ was considered as statistically significant.

\section{RESULTS AND DISCUSSION}

In this study, we evaluated the relationship between endogen amylin hormone and some biochemical, hormonal and bone parameters in pullets. Serum glucose, ALP, triglycerides and cholesterol levels were determined spectrophotometrically, whereas plasma $C T, 1,25(\mathrm{OH})_{2}$ vitamin $\mathrm{D}$, serum osteocalcin were measured using ELISA tests.

While negative correlations were observed between amylin and cholesterol $(p<0.05)$ and triglyceride $(p<0.05)$ concentration, there was no correlation between amylin and glucose concentration (Table 2). A positive correlation between amylin and triglycerides was previously reported in a study with 53 children (Reinehr et al., 2007). However, it remains controversial whether elevated amylin may directly or indirectly induce dyslipidemia. Smith et al. (2000) reported that a bolus injection or infusion with amylin significantly raised total plasma triglyceride levels and reduced the clearance of TG-rich lipoproteins in about 45\%. In another study, Ye et al. (2001) showed that amylin infusion in rats increased not only circulating levels of non-esterified fatty acids and glycerol, but also hepatic triglyceride content. In a recent study, Roth et al. (2008) reported that amylin reduced plasma triglycerides by $31 \%$ and cholesterol by $10 \%$ compared with controls through an increase in lipase secretion, which has a potential role in lysis. Moreover, the weight loss mediated by amylin plus leptin was reported not only to be a result of reduced food intake, but also by the enhancement of systemic lipid metabolism, manifested by significant reduction of plasma triglyceride and total cholesterol levels (Trevaskis et al., 2010). Similarly, Solimann et al. (2013) concluded that amylin lowers serum cholesterol, triglycerides, and LDL and increases HDL. Our findings showed that there was a negative correlation between amylin and cholesterol and triglyceride concentrations in pullets, in agreement with recent studies.

A positive correlation were observed between plasma amylin and serum ALP concentrations (Table 2). Alkaline phosphatase is essential for the process of mineralization, in which minerals such as calcium and phosphorus are deposited in developing bones and teeth. Mineralization is critical for the formation of strong and rigid bones. The role of ALP in bone mineralization was demonstrated during osteoblastic differentiation and growth plate cartilage calcification in previous studies. In both tissues, bone and calcifying

Table 2 - Relationships between plasma amylin concentrations and plasma $\mathrm{CT}, 1,25(\mathrm{OH})_{2}$ vitamin $\mathrm{D}$, and serum osteocalcin, glucose, ALP, triglyceride and cholesterol concentrations.

\begin{tabular}{lccc}
\hline & & \multicolumn{2}{c}{ Plasma Amylin } \\
\hline Blood Parameters & $\overline{\boldsymbol{x}} \pm$ S.E.M. & $r$ & $\mathrm{p}$ \\
\hline Plasma Amylin $(\mathrm{pMol})$ & $23.1 \pm 3.5$ & $\mathrm{~N} / \mathrm{A}$ & $\mathrm{N} / \mathrm{A}$ \\
\hline Plasma CT $(\mathrm{ng} / \mathrm{mL})$ & $1.89 \pm 0138$ & 0.480 & $0.001^{* * *}$ \\
\hline Plasma 1,25 $(\mathrm{OH})_{2}$ Vitamin D $(\mathrm{ng} / \mathrm{mL})$ & $51.45 \pm 5.69$ & 0.077 & 0.648 \\
\hline Serum Osteocalcin $(\mathrm{ng} / \mathrm{mL})$ & $1.08 \pm 0.08$ & 0.079 & 0.642 \\
\hline Serum Glucose $(\mathrm{mg} / \mathrm{dL})$ & $245.30 \pm 17.60$ & -0.072 & 0.652 \\
\hline Serum ALP IU/L & $446.10 \pm 26.89$ & 0.380 & $0.01^{* *}$ \\
\hline Serum Cholesterol $(\mathrm{mg} / \mathrm{dL})$ & $152.07 \pm 14.18$ & -0.346 & $0.05^{*}$ \\
\hline Serum Triglycerides $(\mathrm{mg} / \mathrm{dL})$ & $117.93 \pm 9.89$ & -0.352 & $0.05^{*}$
\end{tabular}

S.E.M., Standard error of the mean; $\overline{\boldsymbol{x}}$, mean, N/A=not applicable. 
cartilage, ALP is expressed early in development. ALP was one of the first key players in the process of osteogenesis to be recognized (Golub et al., 2007). We determined a positive correlation between amylin and ALP concentrations. This may be due to positive effects of intact amylin on tibial growth plate, trabecular and cortical bone (Cornish et al., 1998b; Guzel et al., 2009).

There was a positive correlation between amylin and calcitonin concentration. CT is the founding member of a small family of polypeptide hormones that comprises of CGRP, adrenomedullin, intermedin, CALCR-stimulating hormone, and amylin or islet amyloid polypeptide (Granholm, 2011; Katafuchi et al., 2003; Roh et al., 2003). Correlation between amylin and calcitonin in the present study were expected because of it has a synergetic effect with calcitonin.

No correlations were found between plasma amylin and 1,25 $(\mathrm{OH})_{2}$ vitamin $\mathrm{D}$ and serum osteocalcin. Elevations in extracellular calcium concentration increase the activity of the enzyme 1- $\alpha$-hydroxylase, which converts 25-hydroxycholecalciferol into 1,25 $(\mathrm{OH})_{2}$ vitamin $\mathrm{D}$, the active form of vitamin $\mathrm{D}$. This activated form of vitamin $D$ increases the absorption of calcium (as $\mathrm{Ca}^{2+}$ ions) by the intestine and stimulates the synthesis of osteocalcin. Osteocalcin is secreted by the osteoblasts (Ahlstrom et al., 2008; Tamura et al., 1992). Both human amylin and CGRP inhibited 1,25 (OH)2 vitamin $\mathrm{D}$-induced bone resorption in osteoblasts and were thought to play a role in bone mineralization and calcium ion homeostasis. Amylin has been reported to have CT-like hypocalcemic activity in humans (Datta et al., 1989), rats (Furnsinn et al., 1993) and hens (Guzel et al., 2009). Amylin and its fragments stimulate the proliferation of osteoblasts while inhibiting bone resorption. This may be explained by the reduction in calcium resorption from the bones and the stimulation of the synthesis of $1,25(\mathrm{OH})_{2}$ vitamin D (Tamura et al., 1992; Cornish et al., 1998b). In the present study, there was no significant correlation between amylin and 1,25 $(\mathrm{OH}) 2$ vitamin $\mathrm{D}$ and osteocalcin levels in pullets.

There were no significant correlations between amylin and tibiotarsal weight, length, or total volume (Table 3). In a previous study, the systemic infusion of amylin (1-8) increased trabecular bone volume by $36 \%$ (Cornish et al., 2000). Similarly, Cornish et al. (1998a) also reported that intact amylin increased trabecular bone volume of tibia by $50 \%$, tibiotarsal length, and skeletal mass in adult male mice.
Table 3 - Relationships between plasma amylin concentrations and tibiotarsal weight, length, and total volume.

\begin{tabular}{|c|c|c|}
\hline Bone Parameters & $\overline{\boldsymbol{x}} \pm$ S.E.M & $\begin{array}{c}\text { Plasma Amylin } \\
r \quad p\end{array}$ \\
\hline Tibiotarsal weight(g) & $7.02 \pm 0.14$ & 0.0780 .646 \\
\hline Tibiotarsal length $(\mathrm{cm})$ & $11.69 \pm 0.13$ & 0.0460 .670 \\
\hline Tibiotarsal total volume $\left(\mathrm{cm}^{3}\right)$ & $6.60 \pm 0.24$ & $0.108 \quad 0.340$ \\
\hline
\end{tabular}

S.E.M., Standard error of the mean; $\overline{\boldsymbol{x}}$, mean, N/A=not applicable.

In conclusion, the present study shows that the action of circulating amylin is interrelated and apparently interact with cholesterol, triglyceride, calcitonin, and ALP levels of pullets. These results may help us to better understand the mode of action of the hormone amylin in the metabolic pathways associated with calcium and lipids in pullets.

\section{REFERENCES}

Ahlstrom M, Pekkinen M, Riehleu U, Lamberg-Allardt C. Extracellular calcium regulates parathyroid hormone-related peptide expression in osteoblasts and osteoblast progenitor cells. Bone 2008;42:483-490

Bronsky J, Prusa R. Amylin fasting plasma levels are decreased in patients with osteoporosis. Osteoporosis International 2004;15:243-247.

Cornish J, Callon KE, King AR, Cooper GJS, Reid IR. Systemic administration of amylin, increases bone mass, linear growth, and adiposity in adult male mice. American Journal of Physiology Endocrinology Metabolism 1998a;275:694-699.

Cornish J, Callon KE, Lin CQX, Xiao CL, Mulvey TB, Coy DH, Cooper GJS, Reid IR. Dissociation of the effects of amylin on osteoblast proliferation and bone resorption. American Journal of Physiology Endocrinology Metabolism 1998b;274:827-833.

Cornish J, Callon KE, Gasser JA, Bava U, Gardiner EM, Coy DH, Cooper GJS, Reid IR. Systemic administration of a novel octapeptide, amylin (1-8) increases bone volume in male mice. American Journal of Physiology Endocrinology Metabolism 2000;279:730-735.

Datta HK, Zaidi M, Wimalawansa SJ, Ghtei MA, Beacham JL, Bloom SR, Macintyre I. In vivo and in vitro effects of amylin and amylin-amid on calcium metabolism in the rat and rabbit. Biochemical and Biophysical Research Communications 1989;162:876-881.

Fu W, Patel A, Jhamandas JH. Amylin receptor: a common pathophysiological target in Alzheimer's disease and diabetes mellitus. Front Aging Neuroscience 2013;5:42. doi: 10.3389/fnagi.

Furnsinn C, Nowotny P, Roden M, Rohae M, Pieber T, Parzer S, Waidhâusl $W$. Insulin resistance caused by amylin in conscious rats independent of induced hypocalcaemia and fades during long term exposure. Acta Endocrinoogyl 1993;129:360-365

Golub Ellis E, Kathleen BB. The role of alkaline phosphatase in mineralization. Current Opinion in Orthopaedics 2007;18:444-448.

Granholm S, Henning P, Lerner UH. Comparisons between the effects of calcitonin receptor-stimulating peptide and intermedin and other peptides in the calcitonin family on bone resorption and osteoclastogenesis. Journal Cell Biochemistry 2011;112:3300-3312.

Guzel S, Gunes N, Yıldız H, Yılmaz B. Effects of amylin on bone development and egg production in hens. Poultry Science 2009;88:1719-1724. 


\section{Correlations between Endogen Amylin Hormone and Some Hormonal, Biochemical and Bone Parameters in Pullets}

Hoppener JWM, Jacobs HM, Wierup N, Sotthewes G, Sprong M, de Vos $P$, Berger R, Sundler F, Ahren B. Human islet amyloid polypeptide transgenic mice: in vivo and ex vivo models for the role of hIAPP in Type 2 Diabetes mellitus. Experimental Diabetes Research 2008;697035. doi: $10.1155 / 2008 / 697035$.

Katafuchi T, Kikumoto K, Hamano K, Kangawa K, Matsuo H, Minamino $\mathrm{N}$. Calcitonin receptor-stimulating peptide, a new member of the calcitonin gene-related peptide family. Its isolation from porcine brain, structure, tissue distribution, and biological activity. Journal of Biological Chemistry 2003; 278:12046-12054.

Lebovitz HE. Adjunct therapy for type 1 diabetes mellitus. Nature Reviews Endocrinology 2010; 6:326-334.

Leighton B, Cooper GJ. Pancreatic amylin and calcitonin gene-related peptide cause resistance to insulin in skeletal muscle in vitro. Nature 1988;335:632-635.

Lutz TA. Amylinergic control of food intake. Physiol Behav 2006;89:465471.

Lutz TA. The role of amylin in the control of energy homeostasis. American Journal of Physiology Regulatory Intera 2010; 298:1475-1484

Miegueu P, St-Pierre DH, Munkonda MN. Amylin stimulates fatty acid esterification in 3T3-L1 adipocytes. Molecular and Cell Endocrınology 2013;366:99-107.

Newberry RC, Webster AB, Lewis NJ and Van Arnam C. Management of spent hens. Journal of Applied Animal Welf Science 1999;2:13-29.

Reinehr T, De Sousa G, Niklowitz P, Roth CL. Amylin and its relation to insulin and lipids in obese children before and after weight loss. Obesity 2007;15:2006-2011.

Roh J, Chang CL, Bhalla A, Klein C, HSU SY. Intermedin is a calcitonin/CGRP family peptide acting through the CRLR/RAMP receptor complexes. Journal of Biological Chemistry 2003; 10.1074/jbc.M305332200.
Roth JD, Roland BL, Cole, RL, Trevaskis JL, Weyer C, Koda JE, Anderson CM, Parkes DG, Baron AD. Leptin responsiveness restored by amylin agonism in diet-induced obesity: Evidence from nonclinical and clinical studies. Proceedings of Nationall Academy Science USA 2008;105:7257-7262. PMID:18458326

Smith D, Mamo JC. Islet amyloid polypeptide (amylin) modulates chylomicron metabolism in rats. Clinical and Experimental Pharmacology \& Physiology 2000;27:345-351

Soliman MM, Ibrahim ZS. Bichemical alterations induced by amylin in wistar rats. American Journal of Pharmacology and Toxicology 2013;8:64-72.

Tamura T, Miyaura C, Owan I, Sud TA. Mechanism of action of amylin in bone. Journal of Cellular Physiology 1992;153:6-14

Trevaskis JL, Lei C, Koda JE, Weyer C, Parkes DG. Interaction of leptin and amylin in the long-term maintenance of weight loss in diet-induced obese rats. Obesity 2010;18:21-26. PMID: 19543217

Westermark P, Andersson A, Westermark GT. Islet amyloid polypeptide, islet amyloid, and diabetes mellitus. Physiological Reviews 2011;91:795826

Wielinga PY, Lowenstein C, Muff S, Munz M, Woods SC. Central amylin acts as an adiposity signal to control body weight and energy expenditure. Physiology Behavior 2010;101:45-52.

Xinwei $H$, Liang $S$, Zongmeng $L$, Haiwei $M$, Zhijie $Y$, Huaixing $L$, Peizhen J, Danxia $Y$, Hongyu W, Xingwang $Y, X u$ L*, Yingying L. Associations of amylin with inflammatory markers and metabolic syndrome in apparently healthy Chinese. PLoS ONE 2011;6:e24815. doi:10.1371/ journal.pone.0024815.

Ye JM, Lim-Fraser M, Cooney GJ, Cooper GJ, Iglesias MA. Evidence that amylin stimulates liysis in vivo: a possible mediator of induced insulin resistance. American Journal of Physiology Endocrinology Metabolism 2001:280:562-569. 
